\title{
東日本大震災の復旧・復興工事における 労働災害の発生状況に関する調査分析
}

\author{
伊藤 和也 $^{1} \cdot$ 高梨 成次 ${ }^{2} \cdot$ 堀 智仁 ${ }^{3} \cdot$ 日野 泰道 $^{4} \cdot$ 吉川 直孝 5 ・

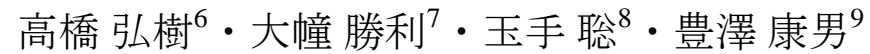 \\ 1正会員 (独)労働安全衛生総合研究所 建設安全研究グループ（テ204-0024 東京都清瀬市梅園1-4-6） \\ E-mail: k-ito@s.jniosh.go.jp \\ 2正会員 (独)労働安全衛生総合研究所 建設安全研究グループ ( $204-0024$ 東京都清瀬市梅園1-4-6) \\ E-mail: takanasi@s.jniosh.go.jp \\ 3正会員 (独)労働安全衛生総合研究所 建設安全研究グループ（†204-0024 東京都清瀬市梅園1-4-6） \\ E-mail: hori@s.jniosh.go.jp \\ 4非会員 (独)労働安全衛生総合研究所 建設安全研究グループ（テ204-0024 東京都清瀬市梅園1-4-6） \\ E-mail: hino@s.jniosh.go.jp \\ 5正会員 (独)労働安全衛生総合研究所 建設安全研究グループ（†204-0024 東京都清瀬市梅園1-4-6） \\ E-mail: kikkawa@s.jniosh.go.jp \\ 6正会員 (独)労働安全衛生総合研究所 建設安全研究グループ（テ204-0024 東京都清瀬市梅園1-4-6） \\ E-mail: takahah@s.jniosh.go.jp \\ 7正会員 (独)労働安全衛生総合研究所 建設安全研究グループ（テ204-0024 東京都清瀬市梅園1-4-6） \\ E-mail: ohdo@s.jniosh.go.jp \\ 8正会員 (独)労働安全衛生総合研究所 建設安全研究グループ (†204-0024 東京都清瀬市梅園1-4-6) \\ E-mail: tamate@s.jniosh.go.jp \\ 9正会員 (独)労働安全衛生総合研究所 建設安全研究グループ（テ204-0024 東京都清瀬市梅園1-4-6） \\ E-mail: toyosawa@s.jniosh.go.jp
}

平成23年（2011年）東北地方太平洋沖地震とその後の大津波や大規模余震によって我が国は甚大な被害 を受け，現在も震災からの復旧・復興に向けた作業が継続されている。このような震災復旧・復興工事で は，通常作業とは異なり狭险な作業箇所での輻輳した環境から労働者が被災する災害事例が多く報告され ている．本論文では，東日本大震災による震災復旧工事における労働災害（死傷病災害）の発生状況につ いて調査し, 震災復旧工事における労働災害の特徴を分析した。ささらに, 地震被害に応じた震災復旧工事 による労働災害発生の蓋然性を調査した既往の研究結果についても検証した.

Key Words : disaster restoration work, labour accident, earthquake, the great east Japan earthquake

\section{1. はじめに}

平成23年3月11日14時46分に発生した平成23年 （2011年）東北地方太平洋沖地震ならびにその後の大 規模余震（以下，東日本大震災とよぶ）は，死者 15,841名，行方不明者2,742名，負傷者6,114名（平成24 年12月12日現在，警察庁発表1)）となる戦後最大の被 害をもたらした。この地震は，海溝型大規模地震であ り，主要動が長時間継続して被害が広範囲に及び，沿
岸部では地震動被害と津波被害が複合するなど，震災 の規模・内容は昨今日本国内で発生していた内陸型活 断層地震とは大きく異なっていた。世界的に見れば, 平成16年12月26日に発生したスマトラ島沖地震（Mw 9.1）をはじめとして，ペルー地震（Mw 8.0，平成19 年8月15日），チ地震（Mw 8.8，平成22年2月27日） など, 海溝型大規模地震が頻発しており, 日本でも太 平洋プレートの海溝型大規模地震である東海, 東南海, 南海地震の発生が懸念されており, 地球全体として巨 
大地震の起こりやすい活動期に入ったと指摘する研究 者もいる ${ }^{2), 3)}$. このような大規模地震発生後には，甚 大な人的被害はもとより，津波災害，地す心゙り・崖崩 れ・落石などの土砂災害，それに伴う河道閉塞，橋梁 の崩落や倒壊等による交通網やライフラインの寸断, 住宅などの建築物や構造物の倒壊等の被害，火災によ る建物の延焼等が広域に発生する. 地震発生直後から 被災地へ物資を供給するためには，寸断された交通網 の迅速かつ的確な復旧工事が必要とされ, 東日本大震 災では「啓開」活動として，地元の建設業者による懸 命な活動が報告されている4 した地域では, 被害者救助のための建物内の緊急工事 とともに，損傷を受けた建物の倒壊による二次災害防 止のための解体撤去工事が必要とされる. このため, 震災復旧工事は, 安全のための十分な調査を待たずし て開始されることが多く, 震災復旧工事を行う作業員 は不安全な状況下で作業を行わざるを得ないことも少 なくない，また，崩れやすい斜面下における土砂の撤 去や, 崩れかけた建物の解体など, いつ崩壊・倒壊し てくるかわからない状況での作業も伴うため, 作業員 自身が二次災害に巻き込まれる恐れがある。特に，大 規模地震ではその後に発生する余震による被害の拡大 も考えられる. 大規模余震の回数は, 新潟県中越地震 において注目されたが，東日本大震災による余震回数 はそれを大きく上回り, 震度5弱以上の余震が58回

(気象庁調べ5)，新潟県中越地震は18回）を数えてい る. そのため, 一般的な作業に比べてより慎重な作業 が要求される.

伊藤らはこのような地震による災害復旧工事中の 労働災害について, 新潟県中越地震 (平成16年) およ び新潟県中越沖地震（平成19年）によって被災した箇 所の災害復旧工事を対象として, 労働災害発生状況の 調査を行い，地震による災害復旧工事における労働㷋 害の特徵や, 地震毎の違いについて分析を行った6). その結果，以下のことを指摘した。 寸なわち，

(1) 地震発生後の災害復旧工事による労働災害は, 建 設業による被災がそのほとんどを占めること，

(2) 建築工事業による死傷病災害は, 地震発生から 1 年 以内に集中寸ること，

(3) 建築工事業では木造家屋建築工事業での発生割合 が $80 \%$ と高く, 土木工事業は, 例えば斜面崩壊が 多発した新潟県中越地震では砂防や道路工事業の 被災が多いなど，地震被害の特徴を反映した業種 での発生割合が高かったこと，

(4) 事故の型について,「はさまれ・巻き込まれ」や

「切れ・こすれ」が多く発生し, 災害復旧工事に おける特徴的な災害として挙げられること,

(5) 事故の型別による労働災害の重篤度は，「崩壊・
倒壞」が高いため注意が必要であることや，障害 を伴う労働災害が多いことから, 建築工事業での

「切れ・こすれ」にも注意が必要であること,

これらの分析結果を基に, 地震被害の状況に応じ た災害復旧工事における労働災害発生の蓋然性につい て検討を行い, 建築工事業では建物の被害状況が深刻 な地域では，建物の解体作業に伴う「切れ・こすれ」， また建物の被害状況が軽微な地域では, 屋根からの 「墜落・転落」に対する地震発生直後からの注意喚起 が必要であることを示した。しかし，二つの地震はい ずれも内陸型活断層地震であり, 被災地域が限定され ることから，より詳細な検討は実施されていない.

本論文では, 東日本大震災によって被災した地域 の震災復旧・復興工事（以下，震災復旧工事とよぶ) における労働災害の発生状況について詳細に調査し, 業種別, 事故の型別の特徵等に加えて, 地域（都道府 県別）毎の労働災害の特徵についても分析を行った. さらに, 地震被害の状況に応じた労働災害発生の蓋然 性の概念的について，その適用性や妥当性を検証した。

\section{2. 東日本大震災での各種被害状況について}

東日本大震災での各種被害状況については, 震災 直後から様々な機関にて調查が実施されている。ここ では, 東日本大震災での被害状況について, 既出の資 料1)，5)，709)を基に簡単にまとめる. 表-1に，東日本大 震災の概要を, 表-2に都道府県別の最大震度（本震）， 人的被害 ${ }^{1)}$, 建物被害 ${ }^{1}$, とともに都道府県別の人口 (平成22年国勢調査) ${ }^{10}$ および住宅総数 (平成20年住

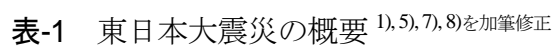

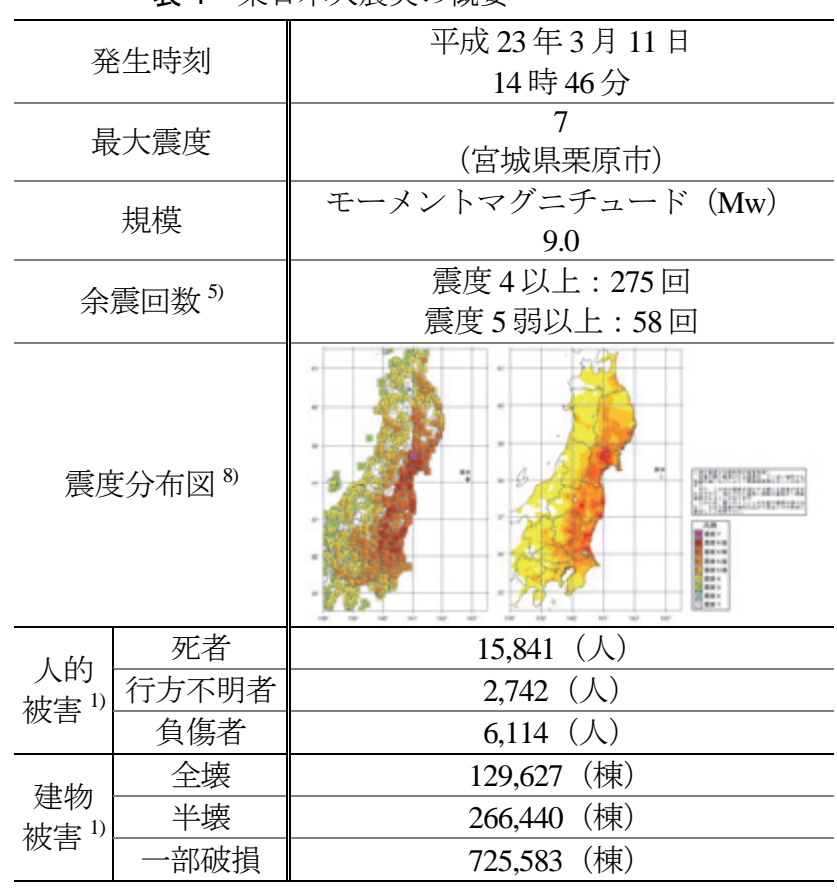


表-2 都道府県別の人口，最大震度（本震），建物数，人的被害，住家被害，土砂災害の発生状況 ${ }^{1), 7), 10), 11)}$

\begin{tabular}{|c|c|c|c|c|c|c|c|c|c|}
\hline & \multicolumn{2}{|c|}{$\begin{array}{l}\text { 基礎情報 } \\
\end{array}$} & \multirow{2}{*}{$\begin{array}{l}\text { 最大震度 7) } \\
\text { 【本震】 }\end{array}$} & \multicolumn{3}{|c|}{ 人的被害 ${ }^{1)} \%$} & \multicolumn{3}{|c|}{ 建物被害 ${ }^{1)} ※$} \\
\hline & $\begin{array}{l}\text { 人口 }{ }^{10)} \\
\text { (人) }\end{array}$ & $\begin{array}{c}\text { 住宅総数 }{ }^{11)} \\
\text { (棟) }\end{array}$ & & 死者 & $\begin{array}{l}\text { 行方 } \\
\text { 不明 }\end{array}$ & 負傷者 & 全壊 & 半壊 & $\begin{array}{l}\text { 一部 } \\
\text { 破損 } \\
\end{array}$ \\
\hline 北海道 & $5,506,419$ & $2,730,500$ & 4 & 1 & & 3 & & 4 & 7 \\
\hline 青森 & $1,373,339$ & 580,800 & 5 強 & 3 & 1 & 109 & 308 & 701 & 958 \\
\hline 岩手 & $1,330,147$ & 549,500 & 6 弱 & 4,671 & 1,192 & 202 & 19,199 & 5,043 & 5,784 \\
\hline 宮城 & $2,348,165$ & $1,013,900$ & 7 & 9,530 & 1,337 & 4,140 & 85,331 & 151,768 & 224,124 \\
\hline 秋田 & $1,085,997$ & 437,400 & 5 強 & & & 12 & & & 3 \\
\hline 山形 & $1,168,924$ & 432,700 & 5 強 & 2 & & 29 & 37 & 80 & \\
\hline 福島 & $2,029,064$ & 808,200 & 6 強 & 1,606 & 211 & 182 & 21,034 & 72,110 & 162,491 \\
\hline 茨城 & $2,969,770$ & $1,223,800$ & 6 強 & 24 & 1 & 709 & 2,620 & 24,158 & 183,675 \\
\hline 栃木 & $2,007,683$ & 839,900 & 6 強 & 4 & & 134 & 260 & 2,109 & 72,143 \\
\hline 群馬 & $2,008,068$ & 855,800 & 6 弱 & & & 38 & & 7 & 17,246 \\
\hline 埼玉 & $7,194,556$ & $3,029,000$ & 6 弱 & & & 42 & 24 & 199 & 1,800 \\
\hline 千葉 & $6,216,289$ & $2,717,700$ & 6 弱 & & & 252 & 799 & 10,024 & 52,026 \\
\hline 東京 & $13,159,388$ & $6,780,500$ & 5 強 & & & 117 & 15 & 198 & 4,847 \\
\hline 神奈川 & $9,048,331$ & $4,067,800$ & 5 強 & & & 134 & & 39 & 445 \\
\hline 新潟 & $2,374,450$ & 929,700 & 5 弱 & & & 3 & & & 17 \\
\hline 山梨 & 863,075 & 398,300 & 5 強 & & & 2 & & & 4 \\
\hline 長野 & $2,152,449$ & 946,300 & 5 弱 & & & 1 & & & \\
\hline 静岡 & $3,765,007$ & $1,597,900$ & 5 弱 & & & 3 & & & 13 \\
\hline 三重 & $1,854,724$ & 791,000 & 3 & & & 1 & & & \\
\hline 高知 & 764,456 & 377,700 & 2 & & & 1 & & & \\
\hline 合計 & - & - & - & 15,841 & 2,742 & 6,114 & 129,627 & 266,440 & 725,583 \\
\hline
\end{tabular}

※未確認情報を含む.

対象とした地震は，本震に加えて，平成 23 年 4 月 7 日に発生した宮城県沖を震源とする地震，平成 23 年 4 月 11 日に発生した福島県浜 通りを震源とする地震, 平成 23 年 4 月 12 日に発生した福島県中通りを震源とする地震, 平成 23 年 5 月 22 日に発生した千葉県北東部を 震源とする地震，平成 23 年 7 月 25 日に発生した福島県沖を震源とする地震，平成 23 年 7 月 31 日に発生した福島県沖を震源とする地震, 平成 23 年 8 月 12 日に発生した福島県沖を震源と寸る地震, 平成 23 年 8 月 19 日に発生した福島県沖を震源と寸る地震, 平成 23 年 9 月 10 日に発生した茨城県北部を震源とする地震，平成 23 年 10 月 10 日に発生した福島県沖を震源とする地震，平成 23 年 11 月 20 日に発生 した茨城県北部を震源とする地震, 平成 24 年 2 月 19 日に発生した茨城県北部を震源とする地震, 平成 24 年 3 月 1 日に発生した茨城県 沖を震源とする地震，平成 24 年 6 月 18 日に発生した宮城県沖を震源とする地震及び平成 24 年 8 月 30 日に発生した宮城県沖を震源とす る地震の被害を含む.

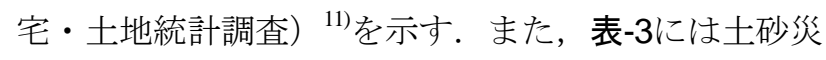
害の発生状況帛を示す。岩手県, 宮城県, 福島県は, 地震発生後の津波の襲来によって甚大な人的被害を受 けている．また，これら東北3県では，建物被害につ いても最大震度が6弱〜7と強い地震動に加えて津波に よって全壊，半壞したものが多い，なお，岩手県は沿 岸域の津波による被害は甚大であったため全壊した建 物被害は多いが, 最大震度は6弱であり, 住宅総数が 宮城県の半分程度, 福島県の7割程度であることから, 全壊以外の建物被害（半壊，一部破損）は宮城県，福 島県と比べると少ない，また，東北3県以外にも茨城 県, 栃木県, 千葉県では半壊や一部破損の被害が多く 見られており, 特に茨城県, 栃木県では屋根部の破損 による被害 ${ }^{12)}$ が多く見られた。これは, 茨城県, 杤木 県の一部地域が震度6強と強い地震動であったことと, 屋根構造等が関連しているものと思われる.また，千 葉県では沿岸部や湿地帯等での液状化による宅地を中 心とした被害 ${ }^{13)}$ が多く報告されている.
表-3 都道府県別の土砂災害の発生状況 ${ }^{9}$

\begin{tabular}{c||r|r|r}
\hline \multicolumn{1}{c||}{} & \multicolumn{3}{|c}{ 土砂災害の発生状況 } \\
\cline { 2 - 4 } & \multicolumn{1}{c}{ 土石流 } & 地すべり & 崖崩れ \\
\hline \hline 北海道 & & & \\
\hline 青森 & & & 1 \\
\hline 岩手 & 1 & & 3 \\
\hline 宮城 & 2 & 2 & 12 \\
\hline 秋田 & & & \\
\hline 山形 & & 2 & 1 \\
\hline 福島 & 1 & 6 & 30 \\
\hline 茨城 & 1 & 1 & 22 \\
\hline 杤木 & 1 & 5 & 5 \\
\hline 群馬 & 1 & & \\
\hline 埼玉 & & & \\
\hline 千葉 & & & 16 \\
\hline 東京 & & & \\
\hline 神奈川 & & & \\
\hline 新潟 & 3 & 13 & 2 \\
\hline 山梨 & & & \\
\hline 長野 & 3 & & \\
\hline 静岡 & & & \\
\hline 三重 & & & \\
\hline 高知 & & & \\
\hline \hline 合計 & 13 & & \\
\hline
\end{tabular}


表-4 東日本大震災による業種別労働災害発生状況 ${ }^{14)}$

\begin{tabular}{c||rl|rl}
\hline \multicolumn{1}{c||}{} & \multicolumn{2}{|c|}{ 震災直接 } & \multicolumn{2}{|c}{ 震災復旧 } \\
\hline \hline 製造業 & $806(340)$ & 39 (3) \\
\hline 建設業 & $303(168)$ & $534 \quad(29)$ \\
\hline 陸上貨物運送業 & $236(153)$ & $10(0)$ \\
\hline その他 & $1,482(653)$ & $61 \quad(4)$ \\
\hline \hline 全産業 & $2,827 \quad(1,314)$ & $644 \quad(36)$ \\
\hline \hline
\end{tabular}

平成 23 年発生分は確定値, 平成 24 年発生分は平成 24 年 9 月 30 日までの速報值（いずれも厚生労働省調べ）

\section{3. 東日本大震災での労働災害の発生状況}

東日本大震災での労働災害の発生状況について, 地震が直接的な原因となって発生した災害（震災直 接）と震災復旧工事中の災害（震災復旧）に分類し， 厚生労働省が労働災害統計で使用している分類方法に 従った業種別の発生件数を表-4にまとめた ${ }^{14)}$.ここで, 括弧内は死亡者数を示している（内数）.

東日本大震災を直接の原因とする死傷者数は全産 業で2,827人であり，そのうち死亡者数は 1,314 人であ った．平成22年の業種別死亡災害発生状況は，製造業 が17.7\%（211人），建設業が30.5\%（365人），陸上貨 物運送業が12.9\%（154人）と，これら3つの業種で全 体の6割程度を占めている．東日本大震災における労 働災害発生状況を業種別で見ると, 通常時に災害発生 件数が多い製造業，建設業，陸上貨物運送業以外の 「その他」の産業が死傷者数, 死亡者数ともに全体の 半数を占めている点と製造業が死傷者数, 死亡者数と もに3割弱と建設業よりも多数となる点が特徵的であ る.これは，業種別の就業者数が影響を与えているも のと思われる. 寸なわち，全就業者数に占める平成22 年の産業別シェア（労働力調査 総務省による）によ

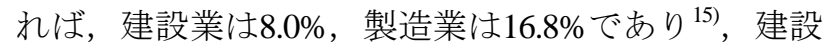
業の就業者数は製造業のそれの約 $1 / 2$ である。つまり, 東日本大震災を直接の原因とする労働災害は, 地震発 生時刻が14時46分と多くの産業が活動中であったこと に加えて，その後に沿岸域を襲った大津波によって就 業者比率が高い産業の労働者が多数犠牲となったこと が一因と考えられる. 次に，震災復旧工事を見ると， 平成24年9月30日現在の速報值で建設業で534件の死傷 災害が発生しており，他の業種と比べて圧倒的に多い なお，建設業の震災復旧工事中に発生した労働災害で は，29名の死亡者も含まれている．震災復旧工事は， 地震によって損傷・損壊した道路や住宅等を復旧・復 興する作業のため, 震災復旧工事中の労働災害は建設 業にて多くなることは, 既往の研究6)でも指摘されて いる. 一方，建設業以外の業種においても建設業ほど は多くないが震災復旧工事中に被災している．特に製 造業やその他の業種では死亡者が3〜4人存在する. 図

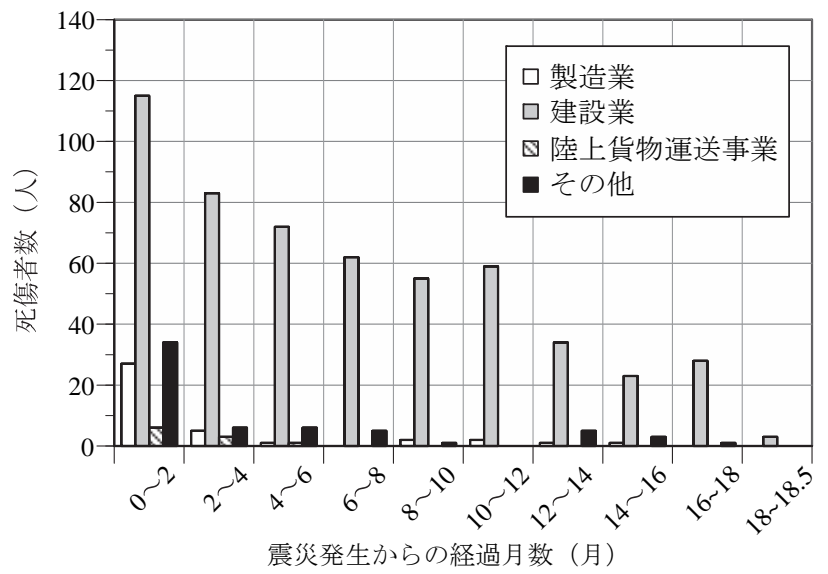

図-1 東日本大震災発生から経過月別の死傷者数 (業種大分類)

-1は, 震災発生から2ヶ月ごとの経過月別の死傷者数 を業種大分類別で示したものである。これを見ると， 全ての業種において震災発生から2ヶ月間に最も多く 労働災害が発生していることが分かる。しかし，建設 業以外の業種では，震災発生から4r月以内には労働 災害が概敉収束している。製造業において被災寸る事 例としては，震災によって倒れた荷棚などを修復する 作業中の被災等が多い。このような短期間で完了する 修復作業は, 震災発生から4ケ月程度である程度収束 したものと推察される. 一方, 建設業では震災発生直 後よりは減少しているが，1年6ヶ月経過した平成24年 9月末現在でも月に12〜15人の割合で被災しており， 未だに収束傾向は見えていない。 これ以降は，建設業 における震災復旧工事中の労働災害に着目した調查・ 分析を行う.

\section{4. 東日本大震災での建設業における震災復旧 工事中の労働災害発生状況}

\section{(1) 調査の対象および項目}

東日本大震災での建設業における復旧・復興工事 による労働災害発生状況について調查・分析を行い, 震災復旧・復興工事における労働災害の特徵などを抽 出した。調查の対象は, 東日本大震災発生後（平成23 年3月11日）から平成24年9月30日の約1年6r月の間に 発生した建設業における休業4日以上の死傷病災害で ある. なお，平成23年の死傷病災害データについては 確定值であるが，平成24年の死傷病災害データについ ては平成24年9月30日現在の速報值（平成24年10月7日 公表）である. 対象となる災害は，平成23年が385件 （うち死亡災害21件），平成24年が149件（うち死亡 災害8件）の計534件（うち死亡災害29件）である，な お, 分析した主な項目は, 発生年月, 発生場所（都道 
表-5＼cjkstart建設業における業種中・小分類 ${ }^{16}$

\begin{tabular}{|c|c|c|}
\hline 分類 & 正式名称 & 図内の略称 \\
\hline "中 & " 土木工事業 & " 土木工事業 \\
\hline \multirow{12}{*}{ 小 } & 水力発電所等建設工事業 & 水力発電所等 \\
\hline & トンネル建設工事業 & トンネル \\
\hline & 地下鉄建設工事業 & 地下鉄 \\
\hline & $\begin{array}{l}\text { 鉄道軌道建設工事業 } \\
\end{array}$ & 鉄道軌道 \\
\hline & 橋梁建設工事業 & 橋梁 \\
\hline & 道路建設工事業 & 道路 \\
\hline & 河川土木工事業 & 河川土木 \\
\hline & 砂防工事業 & 砂防 \\
\hline & 土地整理土木工事業 & 土地整理 \\
\hline & 上下水道工事業 & 上下水道 \\
\hline & 港湾海岸工事業 & 港湾海岸 \\
\hline & その他の土木工事業 & その他の土木 \\
\hline 中 & 建築工事業 & 建築工事業 \\
\hline \multirow{4}{*}{ 小 } & $\begin{array}{l}\text { 鉄骨・鉄筋コンクリート造 } \\
\text { 家屋建築工事業 }\end{array}$ & $\begin{array}{l}\text { 鉄骨・鉄筋コンク } \\
\text { リート造家屋 }\end{array}$ \\
\hline & 木造家屋建築工事業 & 木造家屋 \\
\hline & 建築設備工事業 & 建築設備 \\
\hline & その他の建築工事業 & その他の建築 \\
\hline 中 & その他の建設業 & その他の建設業 \\
\hline \multirow{3}{*}{ 小 } & 電気通信工事業 & 電気通信 \\
\hline & 機械器具設置工事業 & 機械器具設置 \\
\hline & その他 & その他 \\
\hline
\end{tabular}

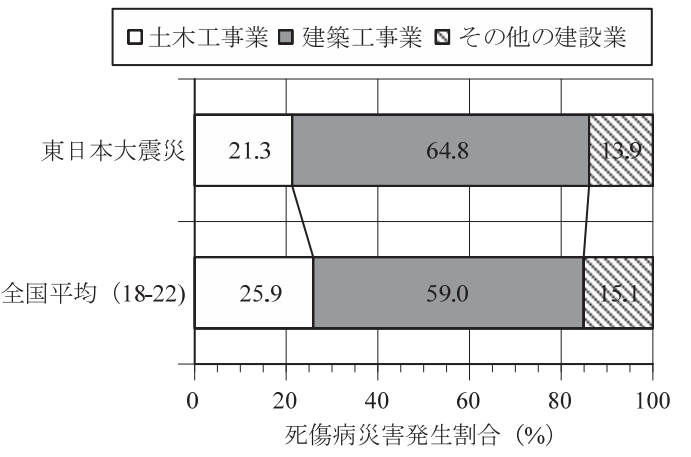

図-2 建設業の業種中分類別の災害発生割合（東日本大震災 と全国平均（平成 18 年～22 年）を比較）

府県単位），災害発生事業場の業種，事故の型等であ る。

\section{（2）業種別の死傷病災害発生状況}

厚生労働省の労働災害統計では，災害発生事業場 の業種を大分類 $\cdot$ 中分類 - 小分類に分けて，業種毎の 災害分析などを行っている ${ }^{16)}$. 建設業では，業種中分 類として土木工事業, 建築工事業, その他の建設業の 3種類に分類されている.さらにこれらの業種は，業 務小分類として表-5に示すように土木工事業では12業 種，建築工事業では4業種，その他の建設業では3業種 に分類されている．ここでは，業種中分類別の死傷病 災害発生割合を平成18～22年の全国平均のそれと比較

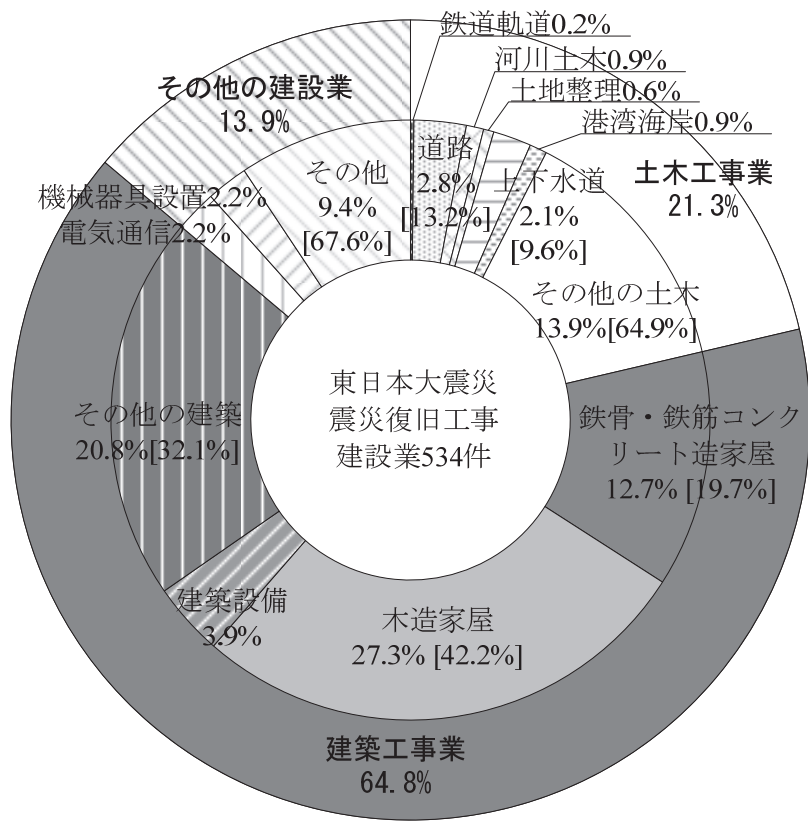

図-3＼cjkstart業種小分類別の死傷病災害発生割合

した傾向を示す，その後，東日本大震災における業種 小分類別での死傷病災害発生割合の傾向について示し， 業種別の死傷病災害発生状況の特徵を把握寸る.

\section{a) 業種中分類による傾向}

図-2は東日本大震災における業種中分類別の死傷病 災害発生割合について，平成18年〜22年の5年間の全 国平均とともに示したものである ${ }^{17)}$. 全国平均では, 土木工事業と建築工事業の死傷病災害発生割合は, そ れぞれ25.9\%，59.0\%であり，建築工事業は土木工事 業の約2.3倍発生している。東日本大震災における死 傷病災害発生割合では，土木工事業が21.3\%，建築工 事業が64.8\%であり，建築工事業は土木工事業の約 3.0 倍発生している，従って，東日本大震災による死傷病 災害割合は全国平均のそれと比較すると，建築工事業 での被災が多い傾向を示している。しかし，これは震 災発生から1年6r月間の比較的短期間の分析結果であ り，土木工事業の震災復旧工事が進んでいないことと も深く関連しているものと思われる.

\section{b) 業種小分類による傾向}

建設業における震災復旧工事の業種別死傷病災害 の発生割合について, 業種小分類での死傷病災害発生 割合から詳細に分析した. 図-3に業種小分類別の死傷 病災害発生割合を示す。なお，割合が多い業種には業 種中分類内での割合についても [ ] にて示している. 図を見ると各業種小分類にて，「その他の土木」，

「その他の建築」「その他」が占める割合が比較的高 いことが分かる.これらの業種小分類の災害発生概要 を見ると, 震災復旧特有の作業である瓦碩処理や解体 が多く含まれていた．土木工事業では，「その他の土 


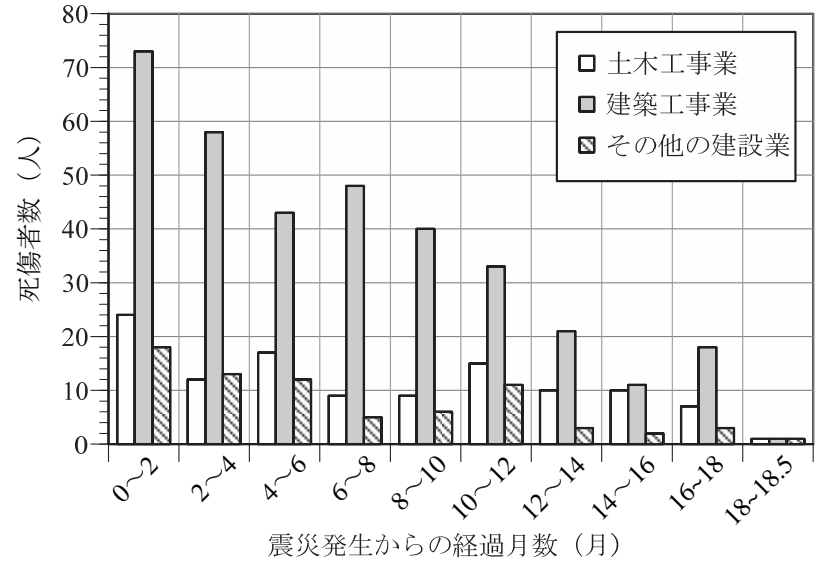

図-4 東日本大震災発生から経過月別の死傷者数 （建設業の業種中分類）

木」を除けば，「道路」（2.8\%），「上下水道」 (2.1\%) の発生割合が高い傾向を示した。また，建 築工事業では，「木造家屋」が27.3\%を占めており， 建築工事業の死傷病災害の半分弱である $42.2 \%$ 木造 家屋建築工事業にて発生していることが分かる.

\section{（3）経過月別死傷病災害発生状況}

建設業の業種中分類（土木工事業，建築工事業， その他の建設業）における震災復旧工事について，震 災発生から2ヶ月ごとの経過月別の死傷者数を図-4に 示す．なお，18〜18.5ヶ月については，平成24年9月 11日〜30日の 2 週間のデータ（速報值）であるため， 件数は少ない，土木工事業では，震災発生から月に4 〜11人のペースで災害が発生している. これに対し， 建築工事業では，震災発生から2ヶ月間に73人の災害 が発生し，その後周期的な増減はあるが，減少傾向を 示している。しかし，震災から1年6r月経過した段階 でも月に5人程度の災害が発生している. 新潟県中越 地震について実施した同様の分析では，建築工事業は 地震発生直後に死傷者数が最も多く, 土木工事業は半 年〜1年半に最も多い傾向となり，業種別によって災 害発生時期が異なった ${ }^{6)}$. 東日本大震災から 1 年6r月 までのデータでは，建築工事業で震災発生直後に最も 多く発生している点など，新潟県中越地震と同様の傾 向が見られる．なお，土木工事業については，大規模 な津波災害による震災復旧工事の遅れ等から現在も一 定值を示しているものと思われる.

\section{（4）事故の型別による死傷病災害発生割合の傾向}

図-5は，事故の型別による死傷病災害の発生割合に ついて，平成18年〜 22年の 5 年間の全国平均（図5(a)）と東日本大震災（図-5(b)）によるものとを業種 中分類（土木工事業，建築工事業，その他の建設業）
毎に比較したものである. ここで，事故の型とは，労 働災害の動向を把握するために規定されたものであり， その傷病を与えた起因物に関係した現象を指す ${ }^{16)}$.

以下，全国平均と比較した東日本大震災による死 傷病災害割合の特徵を業種中分類毎に示す.

a) 土木工事業における事故の型別の死傷病災害発生 割合

土木工事業における全国平均の事故の型別死傷病 災害発生割合としては，「墜落・転落」（22.8\%），

「はさまれ・巻き込まれ」（17.1\%），「飛来・落 下」（13.4\%）の順で災害発生割合が高い。東日本大 震災では，「はさまれ・巻き込まれ」が 24.6\%（28 件）と災害発生割合が最も高い傾向が見られた。これ は, 車両系建設機械等と作業員が輻輳して作業を行う など，通常時作業とは異なる作業状況であることが一 因として考えられる，以下，「墜落・転落」（16.7\%， 19 件），「飛来・落下」（13.2\%，15 件），「転倒」

(13.2\%，15 件）の順で高い災害発生割合を示してい る.

b) 建築工事業における事故の型別の死傷病災害発生 割合

建築工事業における全国平均の事故の型別死傷病 災害発生割合としては，「墜落・転落」（39.4\%）,

「切れ・こすれ」（12.6\%），「飛来・落下」

(9.8\%) の順で多く発生している. 東日本大震災で は，「墜落・転落」が 55.2\%（191 件）と建築工事業 の半分以上の事故の型となっており, 特に注意が必要 な事故の型といえる.

\section{c）その他の建設業における事故の型別の死傷病災害 発生割合}

その他の建設業における全国平均の事故の型別死 傷病災害発生割合としては，土木工事業と同様に「墜 落・転落」（34.4\%），「はさまれ・巻き込まれ」

(12.0\%)，「飛来・落下」（10.5\%）の順で多く発 生している. 東日本大震災では, 「墜落・転落」が 37.8\%（28 件）と災害発生割合が高い傾向が見られ, 特に注意が必要な事故の型といえる。

\section{（5）県毎の事故の型別による死傷者数}

死傷者数が多い県である宮城県, 岩手県, 福島県, 茨城県について業種中分類（土木工事業，建築工事業， その他の建設業）毎に事故の型別の死傷者数をまとめ た（図-6）. 以下に，2.で示した各県の特徵（人口, 住宅総数) や東日本大震災での被災状況等を踏まえて 死傷病災害の傾向について考察する。

\section{a) 宮城県}

宮城県の死傷者数を図-6(a)に示す. 宮城県では, 最大震度が 7 の地域（栗原市築館）があり, 沿岸部で 


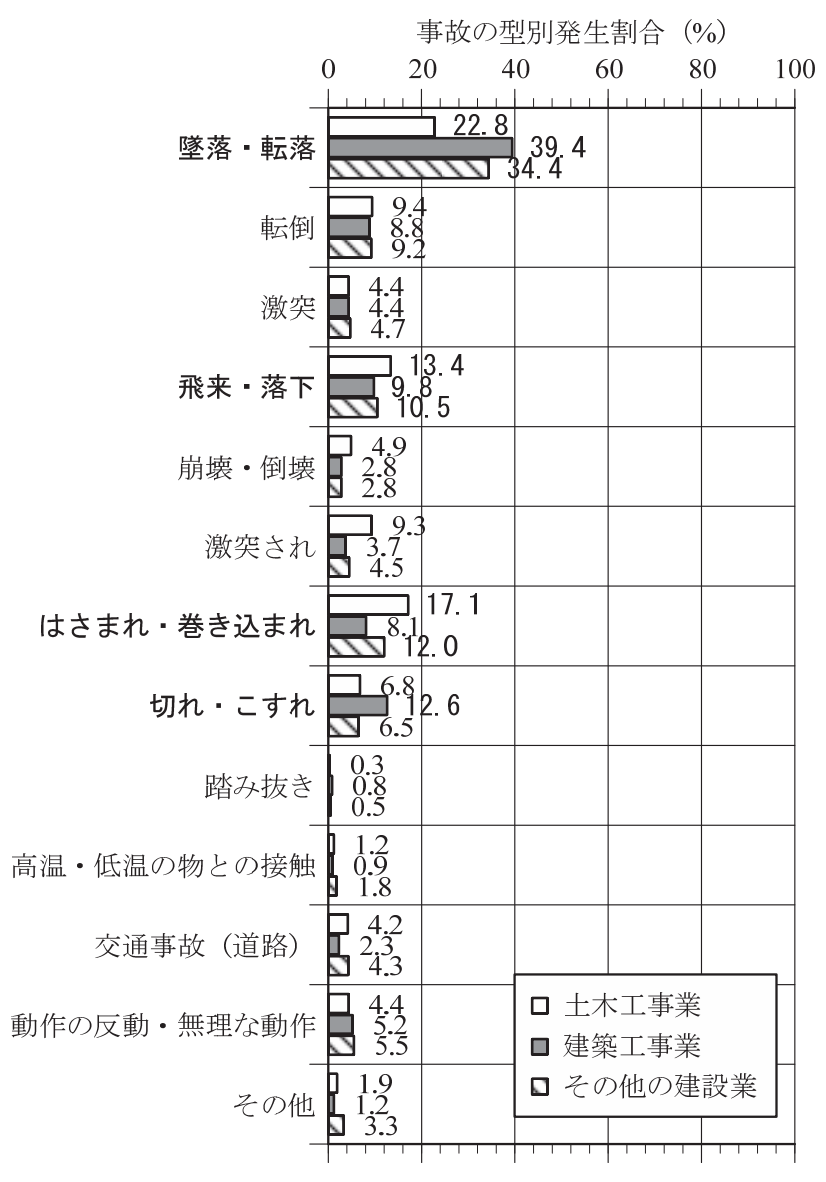

(a) 平成 18 年 22 年の全国平均

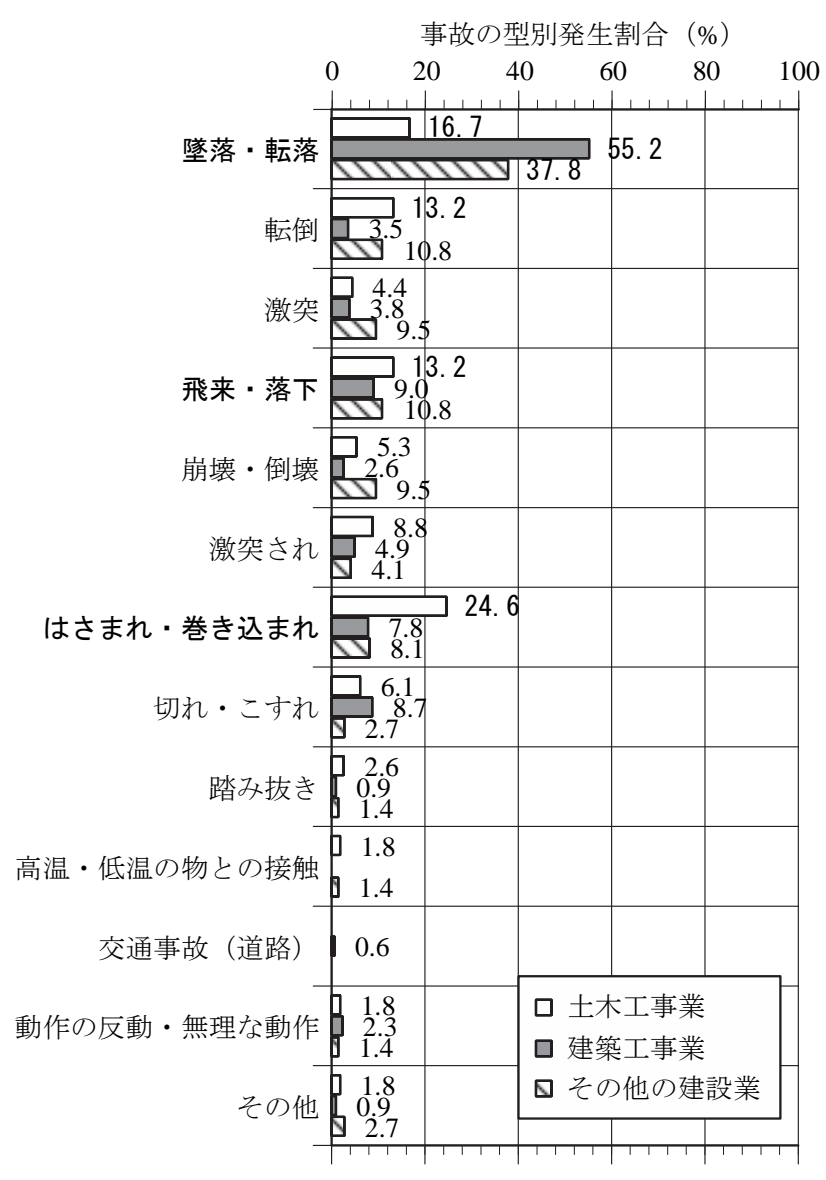

(b) 東日本大震災

図-5＼cjkstart事故の型別死傷病災害発生割合の傾向

は津波によって多くの被害を受けている．まず，建築 工事業では，「墜落・転落」による死傷者数が 80 人 と建築工事業のうち約 45\%を占めている。「墜落・ 転落」による災害以外では，「飛来・落下」（18 人），「はさまれ・巻き込まれ」（18人），「切 れ・こすれ」（16 人）も発生しており，これらにも 注意が必要である.土木工事業では，「はさまれ・巻 き込まれ」が 15 人と「墜落・転落」（11 人）による 災害よりも多い。

\section{b) 岩手県}

岩手県の死傷者数を図-6(b)に示す. 岩手県は他の 3 県と比べて人口や住宅総数が $1 / 2$ 程度であり, 最大震 度も 6 弱であった．また，沿岸部は津波によって壊滅 的な被害を受けている，まず，建築工事業では，「墜 落・転落」による災害が多く, 他の事故の型について は $0 \sim 4$ 人程度となっている. 土木工事業では, 建築 工事業のように「墜落・転落」による災害が突出する わけではなく全ての事故の型が $0 \sim 3$ 件程度発生して いることが特徴として挙げられる.

\section{c) 福島県}

福島県の死傷者数を図-6(c)に示す，福島県は沿岸部
を中心として津波による被害を受け，また，それに関 連して福島第一原子力発電所事故が発生しており, 立 ち入り禁止区域等が存在する. 福島県では, 建築工事 業の「墜落・転落」による死傷者数が 40 人と建築工 事業のうち 7 割弱を占めており,「墜落・転落」によ る災害への対応が当面の課題であることが言える. 土 木工事業では, 岩手県と同様に全ての事故の型が 0〜 3 件程度発生している.

\section{d) 茨城県}

茨城県の死傷者数を図-6(d) に示寸. 茨城県も沿岸 部は津波による被害を受けている。.さらに最大震度が 6 強の地域があり, 屋根部の破損等住家の一部破損が 多く報告されている，建築工事業では，「墜落・転 落」による死傷者数が 48 名と建築工事業のうち約 80\%を占めており, 福島県と同様に「墜落・転落」災 害への対応が当面の課題といえる．これは，上述の被 害状況と対応するものである. 土木工事業では，宮城 県と同様に「はさまれ・巻き込まれ」による災害が 7 人と「墜落・転落」（3 人）よりも多い特徵が見られ る. 


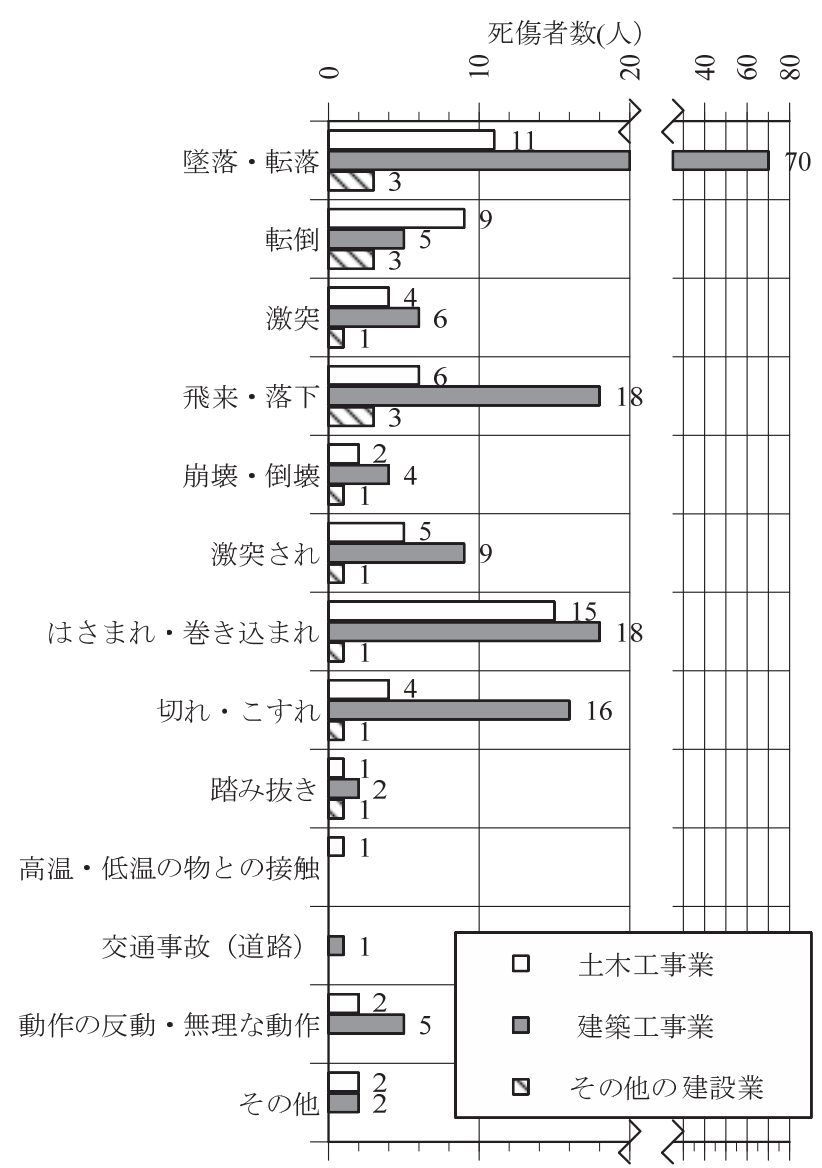

(a) 宮城県

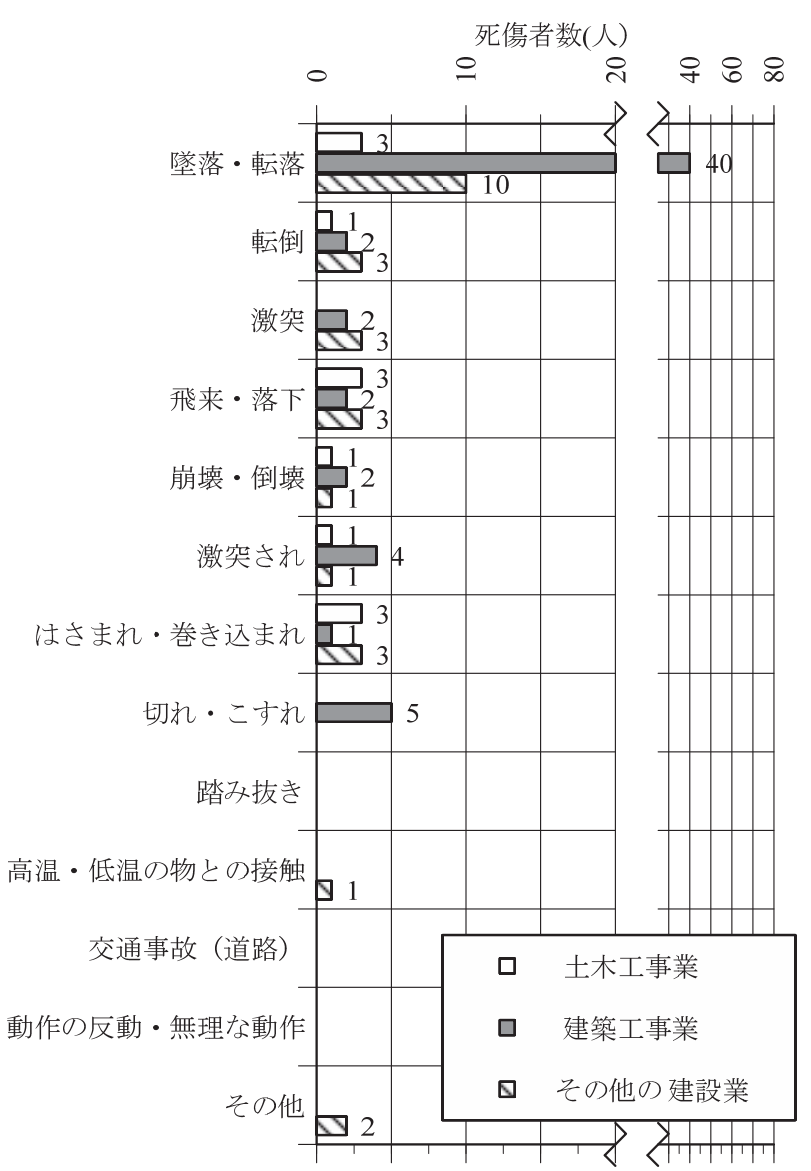

(c) 福島県

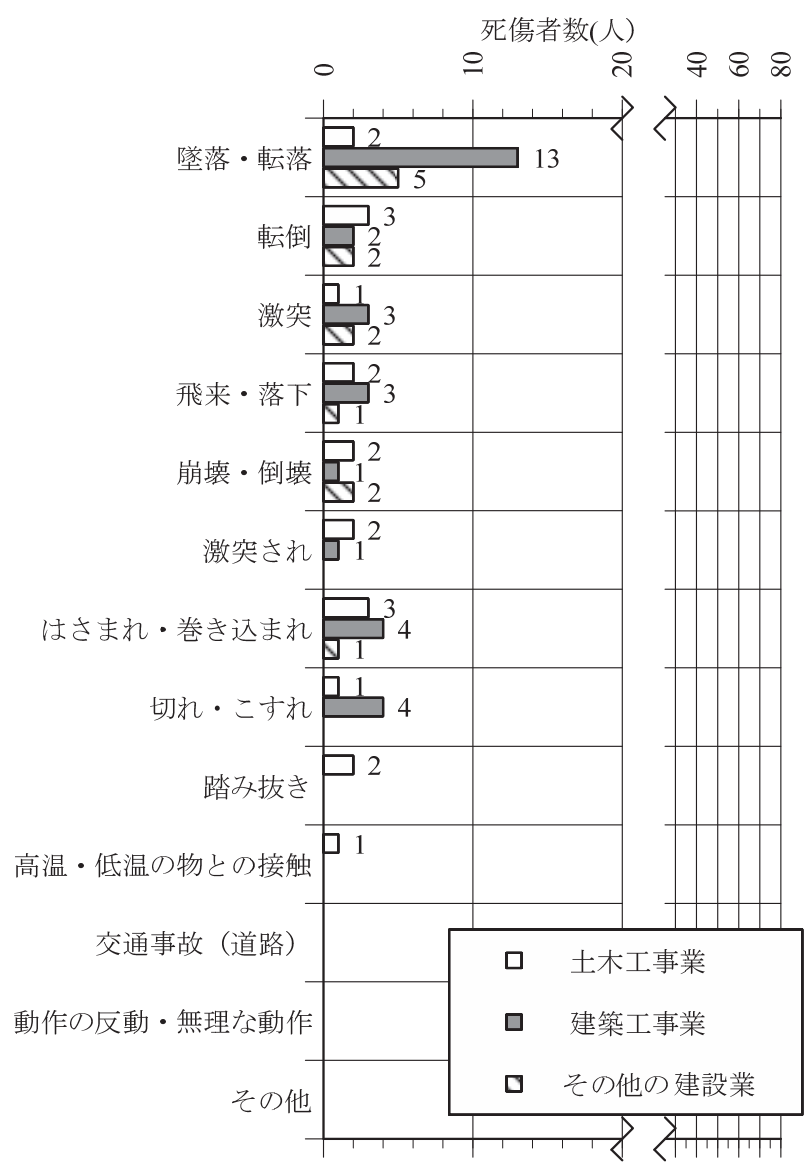

(b) 岩手県

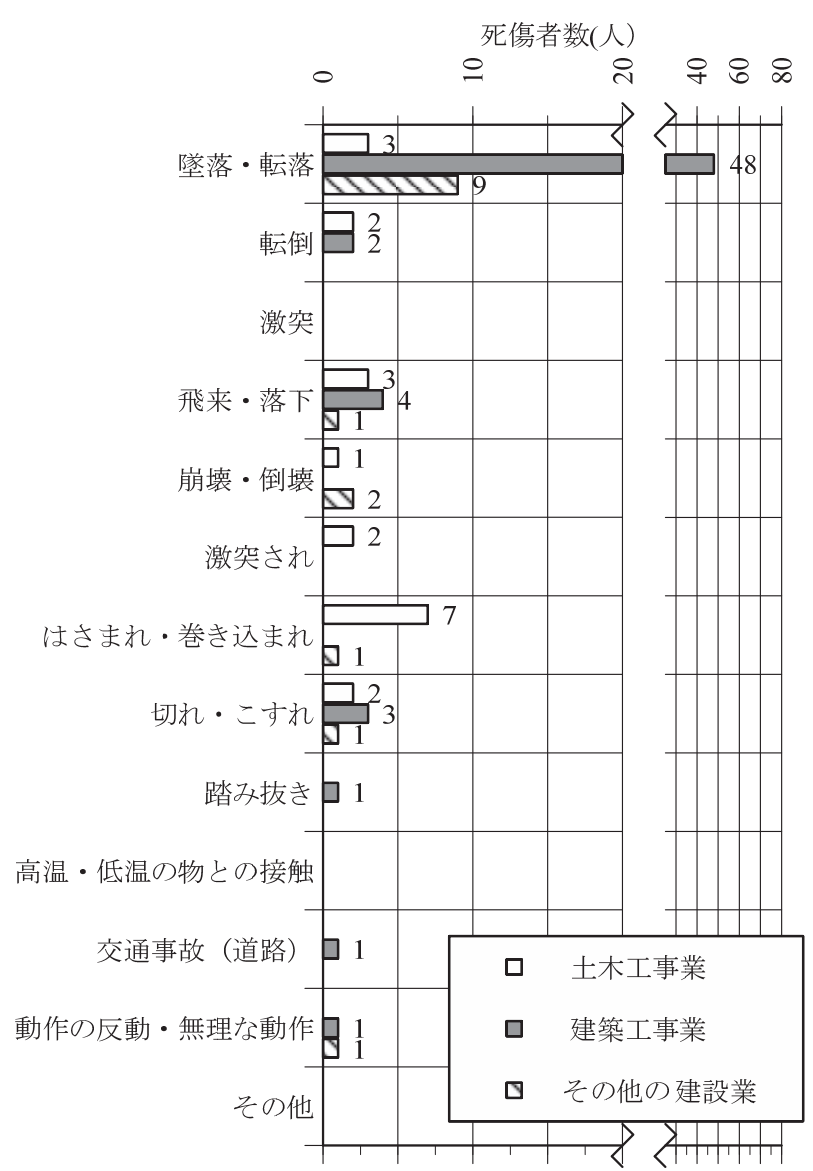

(d) 茨城県

図-6 事故の型別死傷病災害発生割合の傾向（各県の特徵） 
業種中分類毎による事故の型別の死傷者数の各県 の特徵と各県の基礎データや東日本大震災による被災 状況等から東日本大震災による震災復旧工事の死傷病 災害発生割合の特徴を把握すると，以下のようになる。 土木工事業にて全国平均と比べて発生割合が高い「は さまれ・巻き込まれ」による災害は, 宮城県と茨城県 で多く発生していた，建築工事業にて発生割合が高い 「墜落・転落」による災害は，宮城県，岩手県，福島 県, 茨城県の全ての県で多く発生していたが，特に福 島県と茨城県では，建築工事業の大部分が「墜落・転 落」による災害であった。

\section{5. 地震の被害状況に応じた震災復旧工事にお ける労働災害発生の蓋然性に関する検証}

\section{（1）地震被害に応じた震災復旧エ事における労働災 害発生の蓋然性について}

伊藤らは地震による復旧工事中の労働災害につい て, 被害レベルによる復旧曲線と事故の型に応じた労 働災害発生の蓋然性から，地震被害に応じた災害復旧 工事による労働災害発生の蓋然性について検討を行っ た6)。しかしながら, 対象とした新潟県中越地震や新 潟県中越沖地震は内陸型活断層地震であったため, 被 害地域が新潟県に限定されており，死傷病災害データ の分類は県単位が限度であることから, 被害状況の違 いによる事故の型別の労働災害発生の蓋然性について は詳細な把握が出来なかった。一方, 東日本大震災で は津波被害が甚大であった岩手県，宮城県，福島県を 中心として, 茨城県や栃木県などの東日本の広域にわ たって被害を受けていることや，その被害状況が各県 で異なっていることから，被害状況の違いによる事故 の型別の労働災害発生蓋然性の検証を行った。ここで は，震災発生から1年6r月のデータを使用している点 と，4.(2)の結果から，建築工事業に対象を絞って示す.

\section{（2）建築工事業における災害復旧工事における労働 災害の時間経過とその傾向}

建築工事業における災害復旧工事中の労働災害の 発生蓋然性について, 伊藤らは幾つかの業種（小分 類）を抽出して，被害規模（軽微〜重大）と復旧まで の時間についての概念図を例示をしている6 ${ }^{6}$. 図-7は, 木造家屋における災害復旧工事中の労働災害の被害規 模と復旧の時系列を概念的に示したものである. 木造 家屋の場合, 屋根瓦の落下などの軽微な被害について は, 地震発生直後からブルーシート養生を経て瓦替え 作業を行う. そのため, 地震発生から数日〜数週間の 期間で現状復旧寸る。しかし，大規模半壊や全壊の家 屋については, 家屋を解体した後に新たに家屋を建て

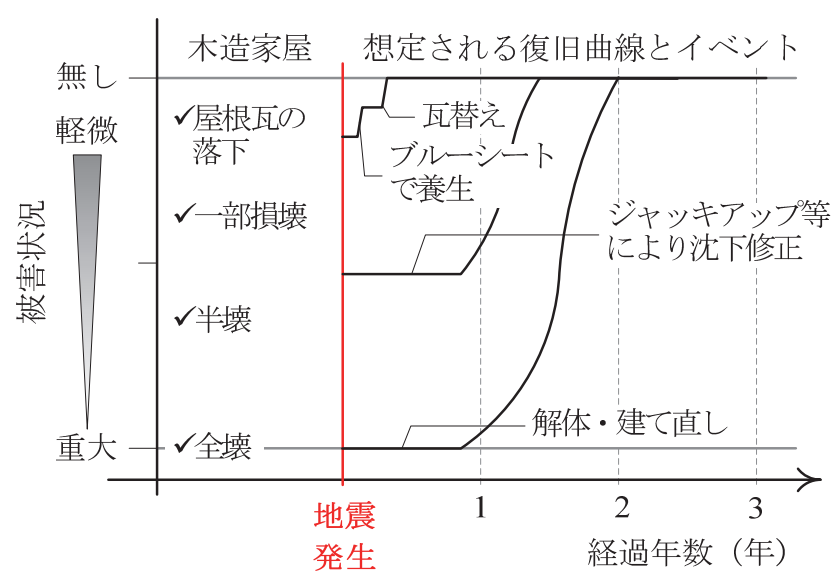

図-7＼cjkstart地震の被害状況に応じた木造家屋での災害復旧工事に おける復旧曲線とイベントの概念図 ${ }^{6)}$

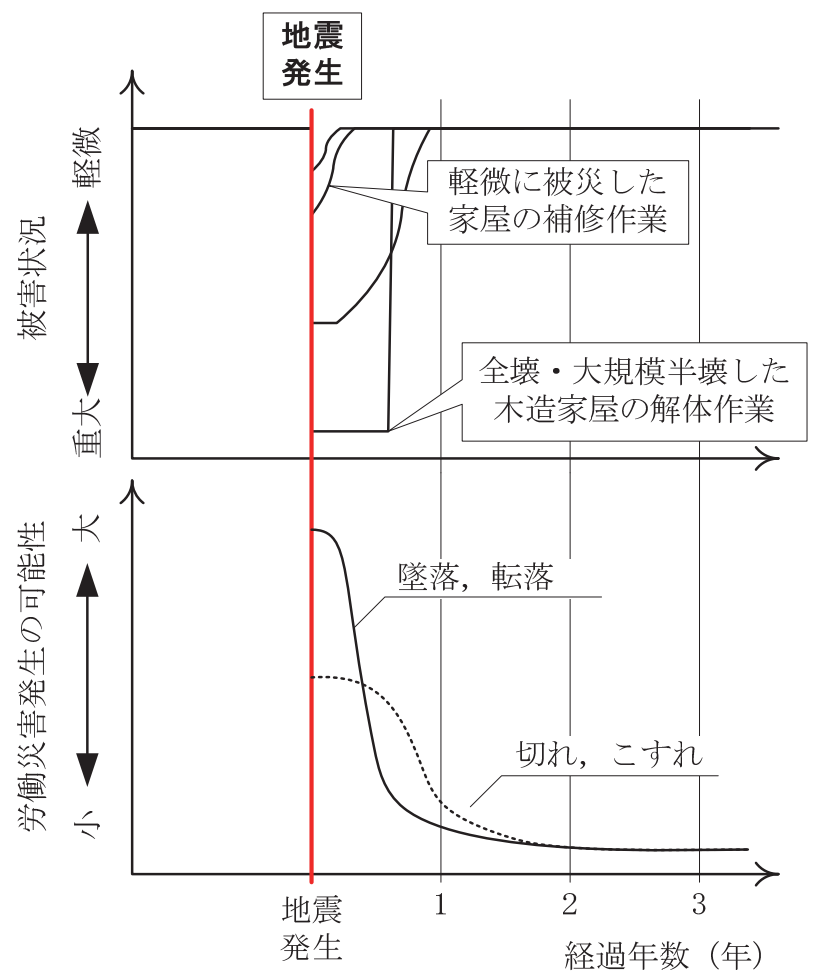

図-8 建築工事業の傾向から見た復旧曲線と労働㷋害発生の 蓋然性についての概念図 ${ }^{6)}$

直したり, 場合によっては造成地の補強工事を行った り寸る必要もあるため, かなりの期間を要することと なる，つまり，被害が軽微である地域は，地震発生か ら比較的早い時期に地震発生前の状態に復旧し, 被害 が甚大な地域では，社会基盤計画等も含めた検討が必 要となり, 復旧・復興までには多くの時間を要するこ とを概念的に示している。 また，図-8は建築工事業の 傾向から見た復旧曲線と労働災害発生の蓋然性につい ての概念図を示したものである．被害状況が軽微〜無 の地域にて軽微に被災した建物は, 日常生活を営むた めに必須であることや，物資供給が可能な被災地域の 


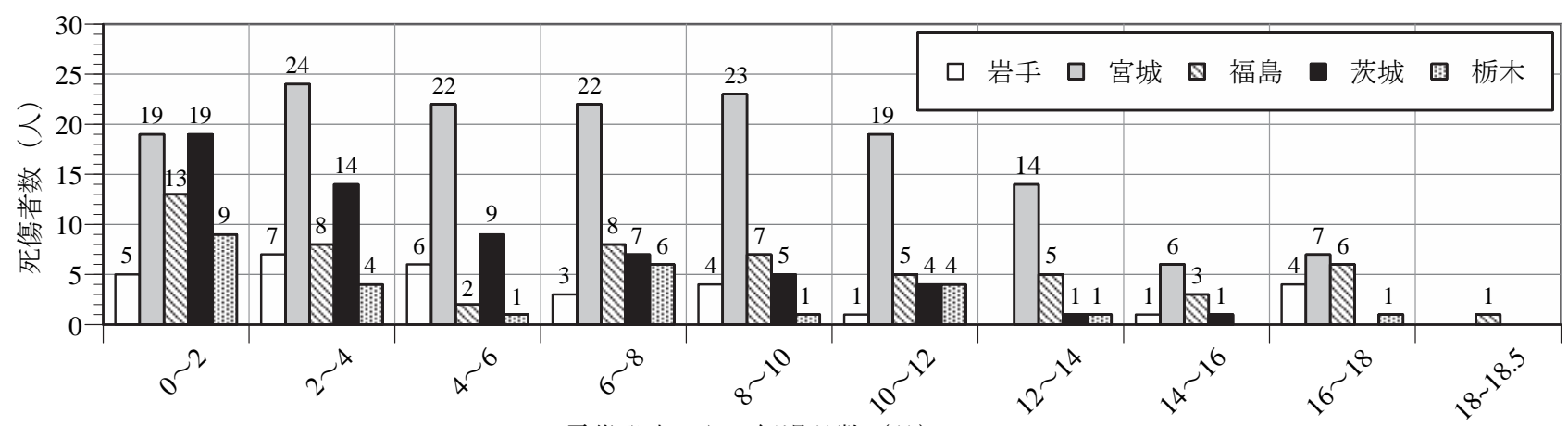

震災発生からの経過月数（月）

図-9 岩手県, 宮城県, 福島県, 茨城県, 栃木県における建築工事業の経過月別死傷者数

外周にあることから，地震発生後速やかに現状復旧さ れる。このような被害状況が軽微の地域では, 地震発 生直後から災害復旧工事が開始され，ハシゴ等を不安 定な場所に設置することによって墜落・転落したり, 一部破損した木造家屋の屋根から墜落・転落寸る事故 が多い。また，全壊や半壊の場合の解体作業に伴う

「切れ・こすれ」の事故に注意が必要となり, それら が時間差を有して発生することを示している. 図-8に 示すような概念が震災復旧工事全体に適用できるかを 検証した。

図-9は岩手県, 宮城県, 福島県, 茨城県, 栃木県に おける建築工事業の震災発生から2ヶ月ごとの経過月 別死傷者数を示したものである. 被害が甚大であった 岩手県, 宮城県, 福島県では, 特に宮城県では震災発 生から 1 年以内において 9 人/月以上の死傷者数が断続 的に発生しており，他県の傾向とは異なっている．ま た, 岩手県, 福島県, 杤木県については, 一旦死傷病 災害が減少した後に再び増加する傾向を示している. 建物被害が比較的軽微であった茨城県や杤木県では, 震災発生直後に多くの死傷病災害が発生していたが, 時間経過により収束する傾向を示している.このよう に, 震災発生直後に最も多く死傷病災害が発生してい た宮城県と茨城県では，震災発生からの経過時間によ って異なる災害発生状況を示している点は, 被害規模 の違いによるものと考えられる，そこで，各県の災害 発生状況について, 事故の型に着目してより詳細な分 析を実施した。

\section{（3）建築工事業における事故の型別の死傷病災害か ら見た労働災害発生の時間経過とその傾向}

図-10は, 岩手県, 宮城県, 福島県, 茨城県の建築 工事業による死傷病災害を事故の型別に分類し，震災 発生から2ヶ月ごとの経過月別傾向を示したものであ る.4.(4)にも示したが，建築工事業では「墜落・転 落」による死傷病災害が約半数から約 8 割を占めてい
る.「墜落・転落」による死傷者数の推移を見ると， 震災発生から2ヶ月間では茨城県が最も多く（15件） 発生していたが，2〜4ケ月では宮城県（16件）が多く なり，県によって災害の発生時期が異なる傾向を示し た．表-2のように茨城県と宮城県では建物被害のうち 全壊棟数では約35倍, 半壊棟数では約6倍の大きな差 があるが，一部破損棟数では1.2倍程度とほぼ同等で ある。つまり，建築工事業の「墜落・転落」による死 傷病災害は, 震災直後に一部破損した建物の修繥もし くは応急復旧するための工事量に影響するものと考え られる。つまり, 同じ事故の型でも, 被害程度の違い によって復旧過程も時間差を有するため労働災害発生 の蓋然性が変化することを示している. これらの結果 は，伊藤らが示した概念が妥当であったことを示して いる. 震災直後の被災事例としては, 被災した屋根瓦 を補修する応急工事として屋根に登ってブルーシート 等をかける作業中に屋根やハシゴから墜落・転落する 事例が多かった．また，「墜落・転落」災害が占める 割合は, 岩手県と宮城県は比較的低い傾向が見られる が, 福島県と茨城県は震災発生直後から「墜落・転 落」災害が多くを占めている様子が分かる。これは, 岩手県と宮城県では, 津波による瓦砂処理作業など被 害が甚大な箇所の復旧作業もあり，「墜落・転落」以 外の事故の型での災害が発生しているためである。一 方，岩手県や宮城県と同様に津波による大きな被害を 受けている福島県が茨城県の傾向と類似しているのは, 福島県内で大きな被害を受けた地域が東京電力福島第 一原子力発電所の事故によって立ち入りが制限され,

復旧・復興が進んでいないためではないかと思われる。 このように東日本大震災のような大規模かつ広範 囲にわたる災害復旧工事では, 様々な要因によって複 雑な復旧過程を経るが, 復旧過程に応じた労働災害防 止対策の重点化を図ることで労働災害を減少できる可 能性を示したものといえる. 


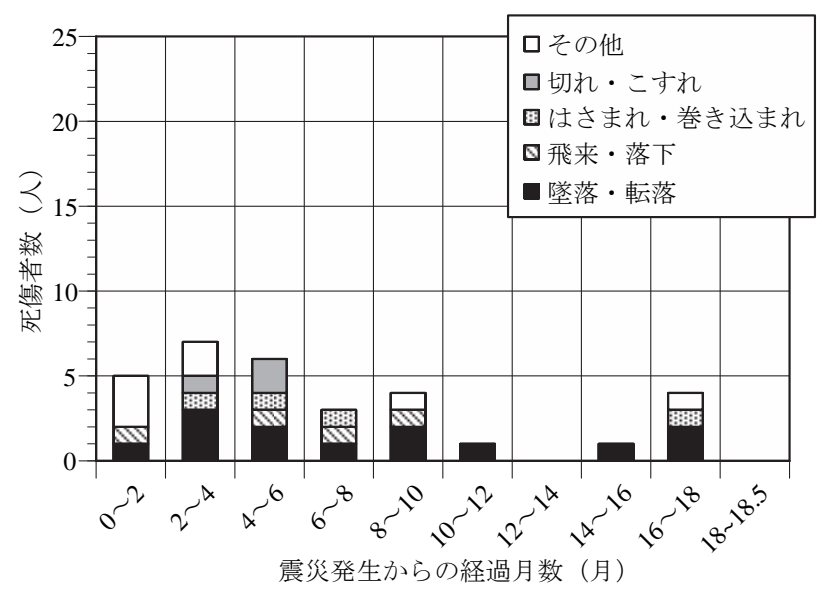

(a) 岩手県

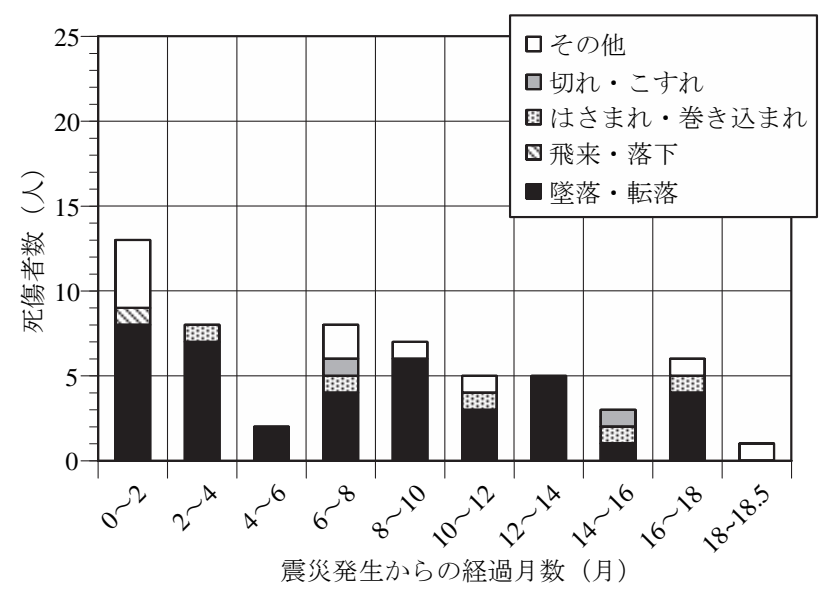

(c) 福島県

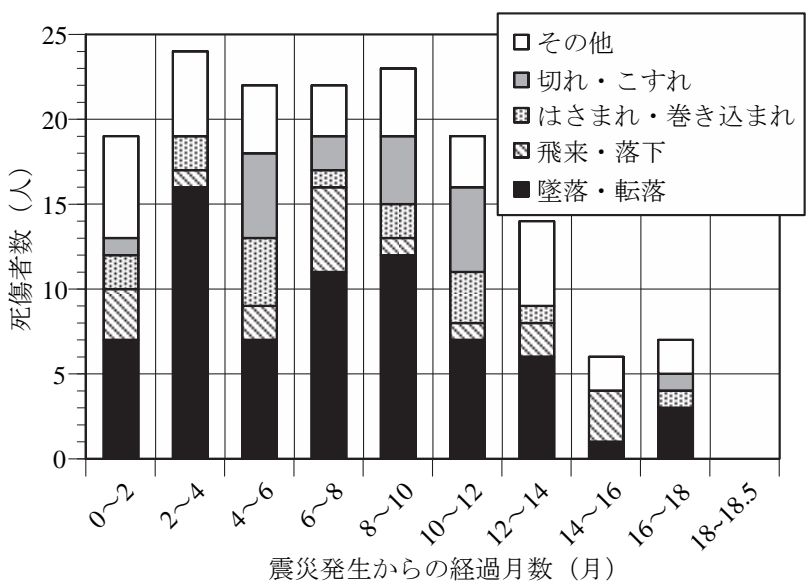

(b) 宮城県

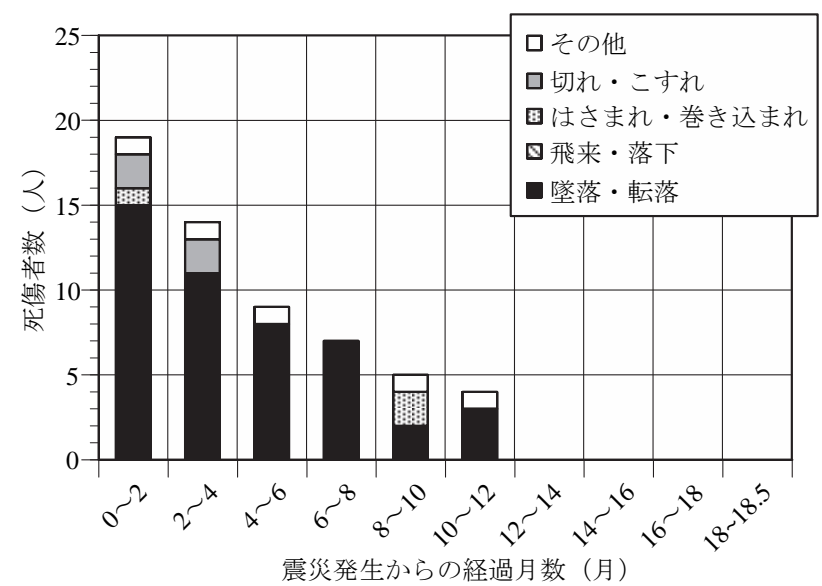

(d) 茨城県

図-10 岩手県, 宮城県, 福島県, 茨城県の建築工事業における事故の型別の経過月別死傷病災害件数

\section{（4）建物の被災状況と建築工事業の「墜落・転落」 災害の関係}

建築工事業の「墜落・転落」災害は，建物被害の うち一部破損した建物の復旧工事と密接な関係がある ことが分かった。 そこで，建物被害（一部破損）と建 築工事業の「墜落・転落」災害の関係について整理し た．図-11は，建物被害（一部破損）と建築工事業の 「墜落・転落」による死傷者数を，建物被害（一部破 損）が発生した16都道府県についてプロットしたもの である．ここで原点 $(0,0)$ 付近にある○点は，「墜 落・転落」による死傷者が1名である青森県, 埼玉県, 東京都と死傷者が0名である北海道, 秋田県, 群馬県, 神奈川県, 新潟県, 長野県, 静岡県の合計10都道府県 である。 さらに，同図には新潟県中越地震と新潟県中 越沖地震における新潟県のデータも加えた. 同図から 岩手県と千葉県を除くと一部破損棟数が増加寸ると死 傷者数も増加する線形関係となることが分かり, 以下 の式で与えることが出来る.

$$
y=2.67 \times 10^{-4} x
$$

ここで， $x$ は建物被害（一部破損棟数），y は建築工 事業の「墜落・転落」による死傷者数（人）である. (1)式の相関係数は, 岩手県と千葉県の結果も含めて 0.962であり強い相関がある. なお，千葉県の場合， 住家被害の一部破損の中に, 浦安市や香取市などの沿 岸部や湿地帯等での液状化被害によるものも含まれて おり，「墜落・転落」災害とは関係がない場合が多い ことが影響している．また，岩手県の場合，災害事例 の半数は住家被害以外のホテルや漁業関係施設での被 災が含まれていた，そのため，住家被害の件数である 一部破損棟数とは整合しなかったものと思われる.

建物被害については, 内閣府中央防災会議にて今 後発生する巨大地震に関する被害予想を行っている ${ }^{17}$. 今回, 得られた知見を利用寸ることによって, 震災発 生後にどの箇所で労働災害が発生しやすいのかを概略 的に事前把握寸ることにより, 大震災発生後の労働災 害防止対策の重点化に利用できるものと考えられる. 


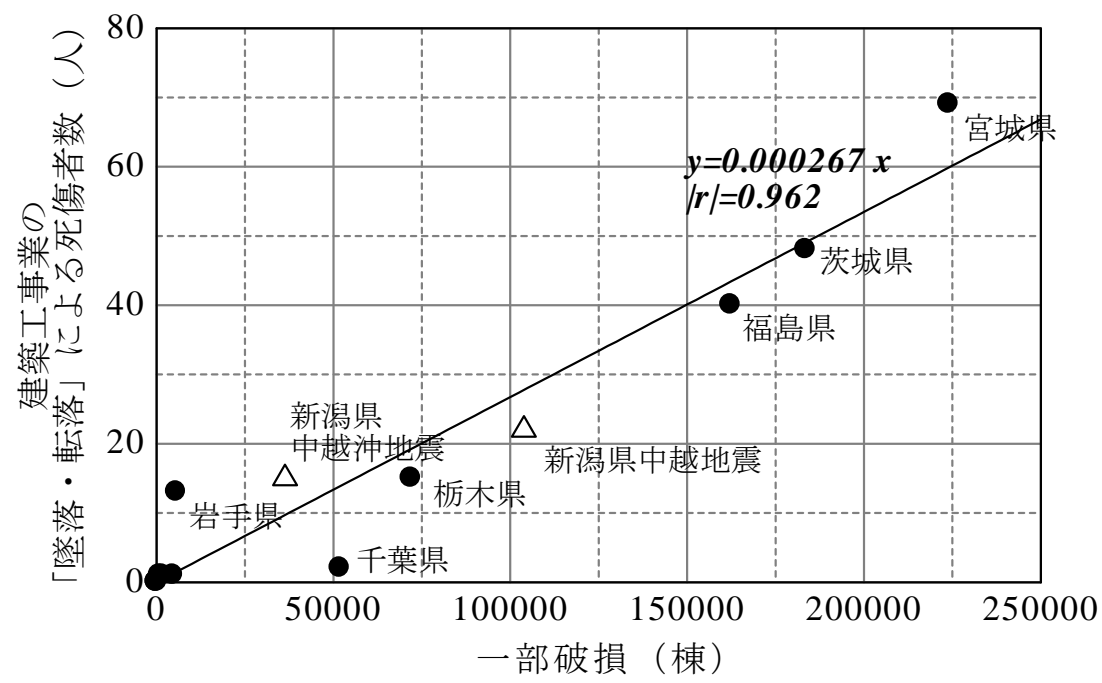

図-11 建物被害（一部破損）と建築工事業の「墜落・転落」による死傷者数の関係

\section{6. まとめ}

本論文は，東日本大震災での労働災害の発生状況に ついて震災発生から約 1 年 6 ケ月間の死傷病災害を調 查し，震災復旧工事における労働災害の特徵や地域毎 の被害と災害の関係などについて分析を行い，地震被 害に応じた災害復旧工事による労働災害発生の蓋然性 の検証を行った．本論文にて得られた知見は，以下の とおりである.

1. 東日本大震災発生後の震災復旧工事による労働災 害は，建設業による被災がそのほとんじを占めて おり，既往の知見と同じ結果となった。しかし， 被害規模が大きい場合には震災発生から 4 ヶ月以 内には製造業などでの被災にも注意が必要である.

2. 震災発生加 2 个月毎の経過月別死傷病災害件数 から，建築工事業による死傷病災害は地震発生直 後に最も多く発生し，土木工事業は 4 11 人の災害 が断続的に発生していることが分かった.

3. 業種別の死傷病災害発生状況について, 業種中分 類（土木工事業，建築工事業，その他の建設業） の全国平均の発生割合と比較すると, 建築工事業 が高いことが分かった。

4. 業種小分類による傾向では，瓦礫処理や解体など の震災特有の作業を含む「その他」にて発生割合 が高かった。また，建築工事業では木造家屋建築 工事業が 42.2\%を占めていた。一方，土木工事業 では，インフラ関係の業種（道路や上下水道）で の発生割合が高かった。

5. 業種別の事故の型について，土木工事業では「は さまれ・巻き込まれ」が，建築工事業では「墜 落・転落」が増加傾向を示した，特に「隊落・転
落」による災害は災害の半分を占めており特に注 意が必要である。

6. 死傷者数が多い 4 県について事故の型別に分類し たところ，建築工事業の「墜落・転落」と土木工 事業の「はさまれ・巻き込まれ」が多く発生して おり，注意が必要であることが分かった。特に， 福島県と茨城県では「墜落・転落」の被災割合が 非常に高いことがわかった。

7. 既往の研究で提案された被害レベルによる復旧曲 線と事故の型に応じた労働災害発生の蓋然性につ いて検証したところ，地震被害に応じて震災復旧 工事の傾向が異なり，被害が軽微であれば震災発 生直後から死傷病災害発生件数が増加し, 被害が 重大であれば時間差を有して死傷病災害発生件数 が増加することが分かった。

8. 建築工事業の「墜落・転落」による死傷者数と建 物被害の一部破損棟数について, 東日本大震災の 各県と過去の地震のデータをプロットしたところ， 相関があることが分かった。これは，大震災の被 害予測の結果を利用することにより震災発生後に どの箇所で「墜落・転落」による労働災害が発生 しやすいかを概略的に事前把握できることを示し ており，労働災害防止対策の重点化に利用できる ものである。

本論文は，震災発生から約1年6力月間の震災復旧工 事中の労働災害について分析を実施したが，震災から の復旧・復興は道半ばであり, ようやく大きなダメー ジを受けた地域の本格的な復旧・復興工事が始まると ころである，今後，被災地での本格的な震災復旧工事 中の労働災害の特徵についても, 継続して調査する予 定である．また，福島第一原子力発電所による放射能 
拡散に伴う除染作業中の労働災害（屋根からの墜落災 害等）も数例報告されており，過去の災害とは異なる 視点からの検討も実施していく予定である.

謝辞 : 本研究は, 厚生労働省科学研究費補助金（労働 安全衛生総合研究事業 課題番号H24一労働一指定一 001 (復興)「大災害時の復旧・復興工事における労 働災害の発生要因の分析及び対策の検討」, 研究代表 者 : 伊藤和也）の補助を得て実施したものです．また， 東日本大震災に関連する労働災害発生状況については, 厚生労働省労働基準局安全衛生部安全課の情報に基づ き分析を行いました．ここに記して，深甚の謝意を表 します，最後に，本論文を查読して頂いた査読者の 方々には，多くの建設的な御指摘および御意見を頂戴 いたしました。ここに記して感謝致します。

\section{参考文献}

1) 警察庁緊急災害警備本部: 平成 23 年（2011 年）東北 地方太平洋沖地震の被害状況々警察措置, 平成 24 年 12 月 12 日広報資料,

http://www.npa.go.jp/archive/keibi/biki/higaijokyo.pdf

2) Michael, A. J. : Random variability explains apparent global clustering of large earthquakes, Geophysical Research Letters, Vol. 38, Issue 21, Page.L21301, 2011. DOI: 10.1029/2011GL049443

3) Beroza, G. C. : How many great earthquakes should we expect?, Proceedings of the National Academy of Sciences of the United States of America (PNAS), Vol. 109, No. 3, pp.651-652, 2012

4) 例えば，日経コンストラクション編：復旧・復興の足 取り「くしの歯作戦」 4 日間で 15 の救援ルート確保 電話が通じなくとも即座に駆けつけた地元建設会社,

「東日本大震災の教訓」土木編 インフラ被害の全貌, pp.164-167, 2011.

5) 気象庁地震火山部：平成 23 年（2011 年）東北地方太 平洋沖地震（平成 23 年 3 月 11 日 14 時〜) 震度 4 以 上の最大震度別地震回数表（本震を含む），平成 24
年 12 月 7 日 17 時現在, http://www.seisvol.kishou.go.jp/eq/2011_03_11_tohoku/yu kan.pdf

6) 伊藤和也，野田昌志，吉川直孝，堀智仁，玉手聡，豊 澤康男，末政直晃 : 新潟県中越地震・新潟県中越沖地 震における災害復旧工事中の労働災害に関する調査・ 分析，土木学会論文集 F6（安全問題）, Vol. 67, No. 1, pp. 27-40, 2011.

7) 気象庁: 平成 23 年（2011 年）東北地方太平洋沖地震, http://www.seisvol.kishou.go.jp/eq/2011_03_11_tohoku/in dex.html

8) 気象庁：災害時地震 - 津波速報 平成 23 年（2011 年) 東北地方太平洋沖地震,

http://www.jma.go.jp/jma/kishou/books/saigaiji/saigaiji_20 1101/saigaiji_201101.pdf

9）国土交通省：災害情報 東日本大震災（116 報），平 成 24 年 12 月 3 日 10:00 作成, http://www.mlit.go.jp/common/000139083.pdf

10) 総務省統計局: 平成 22 年度国勢調査, http://www.stat.go.jp/data/kokusei/2010/

11) 総務省統計局 : 平成20年住宅・土地統計調査, http://www.stat.go.jp/data/jyutaku/2008/

12) 日本建築学会 : 4 関東地方の被害, 2011 年東北地方 太平洋沖地震調査速報, pp.263-362, 2011.

13) 安田進, 原田健二, 石川敬祐 : 東北地方太平洋沖地震 による千葉県の被害, 地盤工学ジャーナル, Vol. 7, No.1, pp.103-115, 2012.

14) 厚生労働省労働基準局安全衛生部安全課業務係 : 労働 災害発生状況, http://www.mhlw.go.jp/bunya/roudoukijun/anzeneisei11/ro usai-hassei/index.html

15) 総務省統計局: 労働力調查, http://www.stat.go.jp/data/roudou/index.htm

16) 労働省安全衛生部安全課編 : 労働災害分類の手引一統 計処理のための原因要素分析一, pp.61-66, 中央労働 災害防止協会, 1999 .

17) 厚生労働省 : 職場のあんぜんサイト, http://anzeninfo.mhlw.go.jp/index.html

18) 内閣府 : 防災情報のページ, http://www.bousai.go.jp/

(2013. 1. 21 受付) 


\section{ANALYSIS OF LABOUR ACCIDENTS OCCURRING IN DISASTER RESTORATION WORK FOLLOWING THE GREAT EAST JAPAN EARTHQUAKE}

\section{Kazuya ITOH, Seiji TAKANASHI, Tomohito HORI, Yasumichi HINO, Naotaka KIKKAWA, Hiroki TAKAHASHI, Katsutoshi OHDO, Satoshi TAMATE and Yasuo TOYOSAWA}

Labour accidents in disaster-relief and disaster restoration work following the Great East Japan Earthquake (2011) were researched and analysed in order to raise awareness of the risks and hazards in such work, over a time period from the occurrence of earthquake up to a 18 months afterwards. In the construction industry, the characteristic accidents resulting in deaths and injuries are "Others," which includes disposal of rubble and demolition of buildings. In the building work, the predominant type of accident is a "fall to lower level," which increases mainly due to the fact that labourers are working to repair houses and buildings. And in the civil engineering, the predominant type of accidents is a being "caught in or compressed by equipment," due to the fact that working areas are limited in terms of space and subject to over-congestion. congested and limited. In addition, the number of the accidents classed as "fall to lower level” in the building work correlates closely with the number of partially damaged houses in disaster-affected areas. 